\title{
ГОСПОДАРСЬКИ КОРИСНІ ОЗНАКИ КОРІВ СИМЕНТАЛЬСЬКОӦ ПОРОДИ РІЗНИХ ЛІНІЙНІЙ В УМОВАХ ОРГАНІЧНОГО ВИРОБНИЦТВА
}

\author{
Кочук-ященко Олександр Анатолійович \\ кандидат сільськогосподарських наук \\ Поліський національний університет \\ ORCID: 0000-0001-5794-5580 \\ E-mail: o.kochukyashchenko@gmail.com
}

Кучер Дмитро Миколайович кандидат сільськогосподарських наук Поліський національний університет ORCID: 0000-0002-1998-6290 E-mail: dkucher@i.ua

Лободзінський Валентин Сергійович Магістрант ORCID: 0000-0001-6824-9601 Поліський національний університет E-mail: lobodzinskyi8@gmail.com

Голяк Вадим Іванович Магістрант ORCID: 0000-0002-8060-3586 Поліський національний університет E-mail: holiak_vadym@gmail.com

У статті висвітлені результати порівняльної оцінки корів-первісток симентальської породи чеської селекції різної лінійної належності за органічного виробництва молока в умовах ПП «Галекс-Агро». Корови-первістки досліджуваних ліній суттєво не відрізняються між собою за живою масою та основними промірами тіла. В цілому корови-первістки симентальської породи стада ПП «Галекс-Агро» характеризуються пропориійною будовою тіла, високоногістю (висота в холиі і в крижах відповідно 134,8-135,3 і 141,6-142,1 см), глибокою та добре розвиненою грудною кліткою (глибина грудей та обхват грудей - 73,5-73,8 та 203,4-204,6 см) як в ширину (ширина грудей за лопатками 50,2-50,9 см), так і в довжину (довжина грудей 80,0-80,4 см) з живою масою 610,6-618,3 ке. Корови мають широкий зад, що забезпечує легкість отелень (щирина в клубах та сідничних горбах відповідно 51,2-51,7 і 32,4-32,6 см). Крупність тварин за основними промірами будови тіла у поєднанні із великою живою масою у межах ліній свідчить про формування молочного типу екстер'єру корівпервісток симентальської породи чеської селекції ПП «Галекс-Агро». Основні індекси будови тіла корів всього стада, так і у межах ліній відповідають молочному типу тварин і свідчать про гармонійність та добрий пропориійний розвиток усіх статей. Значних відмінностей між тваринами різних ліній за морфологічними властивостями вим'я не вдалося встановити. Зокрема обхват вим'я коливався від 118,9 до 122,3 см, довжина 38,7 і 40,3 см, ширина 30,1 і 30,6 см, глибина 29,9 і 30,7 см, відстань від дна вим'я до землі 57,2 і 59,8, довжина передніх дійок 6,3 см в усіх групах, задніх - 5,3 і 5,4 см, відстань між передніми дійками 15,4 і 16,2 см, задніми - 8,2 і 8,6 см, боковими - 13,8 і 14,0. Тварини лінії Редада достовірно переважали ровесниць ліній Хоррора та Морелло за більшістю кількісних показників молочної продуктивності, за якісними показниками (вмістом жиру та білка в молоці) вірогідної міжгрупової різниці не було встановлено. Різниця між лініями у 30 \% випадків виявилась достовірною. Максимальна різниця за показниками молочної продуктивності спостерігалась між лініями Морелло та Редада, яка у 50 \% випадків виявилась достовірною і середній узагальнюючий критерій достовірності Стьюдента становив 1,53. Значення коефіцієнтів фенотипової консолідадації тварин різних ліній характеризуються додатнім значенням і незначною мінливістю. Варто відмітити, що серед усіх блоків досліджуваних ознак у межах ліній від'ємні коефріцієнти фенотипової консолідації виявилися лише у тварин лінії Редада (молочна продуктивність -0,032) та Морелло (індекси будови тіла -0,002). дованість.

Ключові слова: симентальська порода, органічне виробництво, екстер'єр, проміри тіла, індекси, вим'я, консолі-

DOI: https://doi.org/10.32845/bsnau.Ivst.2021.2.13

Порода - структура елементів, основними з яких $є$ типи, лінії і родини. Динамічність та постійний рух, заміна одних елементів породи на інші - більш продуктивніші та цінніші в селекційному процесі дозволяє породі завжди змінюватись у потрібному напрямку. Тобто, процес розвитку породи значною мірою обумовлений генеалогічною структу- рою, на формування якої мають суттєвий вплив заводські лінії. У селекційній практиці розведення за лініями є вищою формою племінної роботи і вважається класичним та одним із основних методів генетичного удосконалення стад і порід при чистопородному розведенні [1, 2]. При цьому лінія збагачується цінною спадковістю родоначальника, індивідуаль- 
ні особливості якого перетворюються у групові. Розведення за лініями дозволяє найбільш ефективно використовувати високоцінних препотентних плідників, створювати великі масиви продуктивних тварин бажаного типу, які стійко передають потомству господарськи корисні ознаки. Ефективність лінійного розведення залежить від числа поколінь ії продовжувачів та наявність у ній бугаїв-лідерів, щоб забезпечити упродовж 4-6 поколінь їхній прогресивний розвиток [3, 4].

Створення у породі ліній, які характеризуються своїми індивідуальними якостями, роблять породу більш пластичною, і дозволяють ефективно здійснювати селекційну роботу. Однією з порід, яка розводиться на теренах Житомирської області є симентальська порода. Саме Житомирська область є лідером за сконцентрованістю цієї породи в Україні [5].

Серед найбільш чисельних господарств в Україні, що займаються удосконаленням симентальської породи, слід відмітити, приватне підприємство "Галекс-Агро" у якому зосереджено 1414 голів, у тому числі 905 корів [6].

Враховуючи вище зазначене, метою наших досліджень $€$ вивчення впливу лінійної належності на показники екстер'єру і продуктивності корів-первісток симентальської породи в умовах ПП «Галекс-Агро» Новоград-Волинського району Житомирської області.

Матеріали та методи досліджень. Дослідження проведені на 169 коровах-первістках симентальської породи ПП «Галекс-Агро» Новоград-Волинського району Житомирської області за матеріалами племінного обліку та результатами власних досліджень.

Для проведення досліджень були відібрані групи коpi, які належать до таких ліній: Хоррора 706945491, Морелло CZ 842871443.72, Редада CZ 711620016.77. Порівнювали лінії чисельністю не менше 25 голів кожної і численністю не менше 3 бугаїв цієї лінії.

Особливості екстер'єру та конституції тварин досліджували на 2-3 місяцях лактації за загальноприйнятими методиками.

Морфолого-функціональні показники вим'я корівпервісток оцінено на 2-3 місяці лактації, за годину до доїння, шляхом огляду та вимірювання.

Оцінку молочної продуктивності корів здійснювали шляхом проведення щомісячного контрольного доїння 3 одночасним визначенням у добових зразках молока вмісту жиру. Відносну молочність обчислювали діленням 4\%-го за вмістом жиру молока, отриманого за 305 днів або скорочену лактацію (не менше 240 днів) на 100 кг живої маси корови.

Відтворну здатність корів вивчали за віком 1-го отелення (міс), тривалістю (днів) сервіс-періоду (СП), періоду тільності (ПТ), міжотельного періоду (МОП), періоду сухостою (ПС) та за коефіцієнтом відтворної здатності (КВ3).

Коефіцієнти фенотипової консолідації господарськи корисних ознак $\left(K_{1}, K_{2}\right)$ та їх середнього значення $\left(\mathrm{K}_{\text {ср.) }}\right.$ обчислювали за формулами Ю. П. Полупана [7].

Статистична обробка результатів проводилась 3 використанням пакету аналізу Microsoft Excel та «STATISTICA13,0» на ПК.

Результати досліджень. Основними завданнями селекційно-племінної роботи у скотарстві $€$ підвищення рівня молочної продуктивності та покращення екстер'єрного типу. Дані ознаки визначаються як генотипом, так і умовами вирощування та подальшого використання при виробництві молока.

Одним із завдань нашої роботи було встановлення впливу лінійної належності корів симентальської породи на їх екстер'єр (табл. 1).

Масо-метричні параметри тулуба корів-первісток різних груп

\begin{tabular}{|c|c|c|c|c|c|}
\hline \multirow{3}{*}{ Показник, одиниці виміру } & \multicolumn{3}{|c|}{ Лінія } & \multirow{2}{*}{\multicolumn{2}{|c|}{$\begin{array}{l}\text { Різниця } \\
\text { min-max }\end{array}$}} \\
\hline & $\begin{array}{c}\text { Xoppopa } \\
(\mathrm{n}=60)\end{array}$ & $\begin{array}{c}\text { Морелло } \\
(\mathrm{n}=34)\end{array}$ & $\begin{array}{l}\text { Редада } \\
(\mathrm{n}=51)\end{array}$ & & \\
\hline & $X \pm S . E$. & $X \pm S . E$. & $X \pm S . E$. & $d \pm S . D$. & td \\
\hline Жива маса, кг & $611,3 \pm 7,44$ & $610,6 \pm 8,57$ & $618,3 \pm 6,97$ & $-7,63 \pm 11,0$ & 0,69 \\
\hline Проміри, см & & & & & \\
\hline висота в холці & $134,8 \pm 0,38$ & $135,3 \pm 0,47$ & $135,3 \pm 0,45$ & $-0,52 \pm 0,59$ & 0,88 \\
\hline висота в крижах & $141,6 \pm 0,43$ & $142,1 \pm 0,57$ & $142,1 \pm 0,53$ & $-0,55 \pm 0,68$ & 0,80 \\
\hline глибина грудей & $73,5 \pm 0,26$ & $73,6 \pm 0,38$ & $73,8 \pm 0,26$ & $-0,31 \pm 0,37$ & 0,84 \\
\hline ширина грудей за лопатками & $50,9 \pm 0,28$ & $50,2 \pm 0,35$ & $50,8 \pm 0,29$ & $-0,71 \pm 0,45$ & 1,58 \\
\hline довжина грудей & $80,4 \pm 0,40$ & $80,0 \pm 0,49$ & $80,3 \pm 0,36$ & $-0,34 \pm 0,63$ & 0,53 \\
\hline обхват грудей & $204,0 \pm 0,98$ & $203,4 \pm 1,17$ & $204,6 \pm 0,84$ & $-1,21 \pm 1,44$ & 0,84 \\
\hline коса довжина тулубу, & $170,6 \pm 0,73$ & $171,4 \pm 0,79$ & $171,7 \pm 0,69$ & $-1,10 \pm 1,00$ & 1,10 \\
\hline ширина в клубах & $51,7 \pm 0,23$ & $51,2 \pm 0,31$ & $51,4 \pm 0,24$ & $-0,46 \pm 0,38$ & 1,21 \\
\hline ширина в сідничних горбах & $32,6 \pm 0,30$ & $32,4 \pm 0,33$ & $32,6 \pm 0,22$ & $-0,24 \pm 0,40$ & 0,59 \\
\hline обхват п'ястка & $19,3 \pm 0,14$ & $19,4 \pm 0,18$ & $19,5 \pm 0,16$ & $-0,14 \pm 0,22$ & 0,63 \\
\hline
\end{tabular}

Нами встановлено, що корови-первістки досліджуваних ліній відрізняються між собою за живою масою та основними промірами тіла. У цілому корови-первістки симентальської породи стада ПП «Галекс-Агро» характеризуються пропорційною будовою тіла, високоногістю (висота в холці в крижах відповідно 134,8-135,3 і 141,6-142,1 см), глибокою та добре розвиненою грудною кліткою (глибина грудей та обхват грудей - 73,5-73,8 та 203,4-204,6 cм) як в ширину (ширина грудей за лопатками 50,2-50,9 см), так і в довжину (довжина грудей 80,0-80,4см) з живою масою 610,6-618,3 кг.
Корови мають широкий зад, що забезпечує легкість отелень (ширина в клубах та сідничних горбах відповідно 51,2-51,7 і 32,4-32,6 см). Обхват п'ястка, який виражає розвиток кістяка та тип конституції тварин, становить 19,3-19,5 см.

За масо-метричними промірами обстежених корів різних ліній абсолютну перевагу встановити не вдалося. Дещо кращими за живою масою та переважною більшістю промірів статей тіла виявилися корови лінії Редада, нижчими показниками даних ознак характеризувалися тварини ліній Хоррора і Морелла, однак різниця між групами у всіх випад- 
ках виявилася не вірогідною.

Відсутність міжгрупової різниці за масо-метричними параметрами тіла, диференційованих за лінійною належністю, пояснюється тим, що дане стадо ПП «Галекс-Агро» формувалось шляхом завозу кращих нетелів, відібраних за екстер'єром і продуктивністю матерів у господарствах Чеської Республіки. У даному господарстві і надалі проводиться селекція тварин за екстер'єром чеськими спеціалістами, які складають і корегують план підбору для даного господарства.

Індекси будови тіла суттєво доповнюють характеристику розвитку корів і дають повне уявлення про пропорційність будови тіла, дозволяють встановити продуктивнотипові відмінності для кожної породи.

Варто відмітити, що основні індекси будови тіла корів всього стада, так і у межах ліній відповідають молочному типу тварин і свідчать про гармонійність та добрий пропорційний розвиток усіх статей. Значення індекса довгоногості, який відображає відносний розвиток кінцівок у довжину і характеризує тип конституції, коливалось від 45,4 до 45,6 \%. Індекс формату, який визначається, як співвідношення довжини тулуба до висоти у холці, менший індекс притаманний молочній худобі варіював в межах 126,4-126,9\%. Індекс компактності - 118,6-119,6 \%, є добрим показником розвитку маси тіла. Уявлення про відносний розвиток тулуба корів визначали за індексом масивності. Значення даного індекса становило 150,3-151,2\%, що свідчить про добру динаміку вікового розвитку тварин.

Уявлення про відносний розвиток скелету дає індекс костистості. У тварин даного стада у межах ліній він становив 14,3 і 14,4. Аналогічна стабільність індексів будови тіла зумовлена тими фракторами, що і проміри будови тіла.

Вим'я $€$ найбільш важливою частиною тіла молочної корови, а його розміри та технологічні параметри визначають рівень їх надоїв. Найкраще для машинного доїння підходить тварини, частки вим'я, яких розвинені рівномірно з дійками оптимальної форми і довжини, розміщеними посередині них. Бажане вим'я корови ванно- або чашоподібної форми, з міцним прикріпленням до черева і розповсюдженням його частин далеко назад за лінію стегна. Вим'я повинно розміщуватись на достатній відстані від землі з глибокою бороздою підтримуючої зв'язки [8-10].

Спеціалісти господарства ПП «Галекс-Агро» приділяють велику увагу морфологічним властивостям вим'я при складанні плану підбору і добирають бугаїв препотентних за цими показниками. Оскільки, доїння корів проводиться у доїльному залі і виставляються відповідні вимоги до даних ознак вим'я корів стада і багатьма вченими встановлена достовірна кореляція між більшістю промірів вим'я і ознаками молочної продуктивності.

Тому нами було досліджено морфологічні властивості вим'я корів симентальської породи різної лінійної належності даного стада (табл. 2).

Морфологічні властивості вимені корів-первісток різних ліній

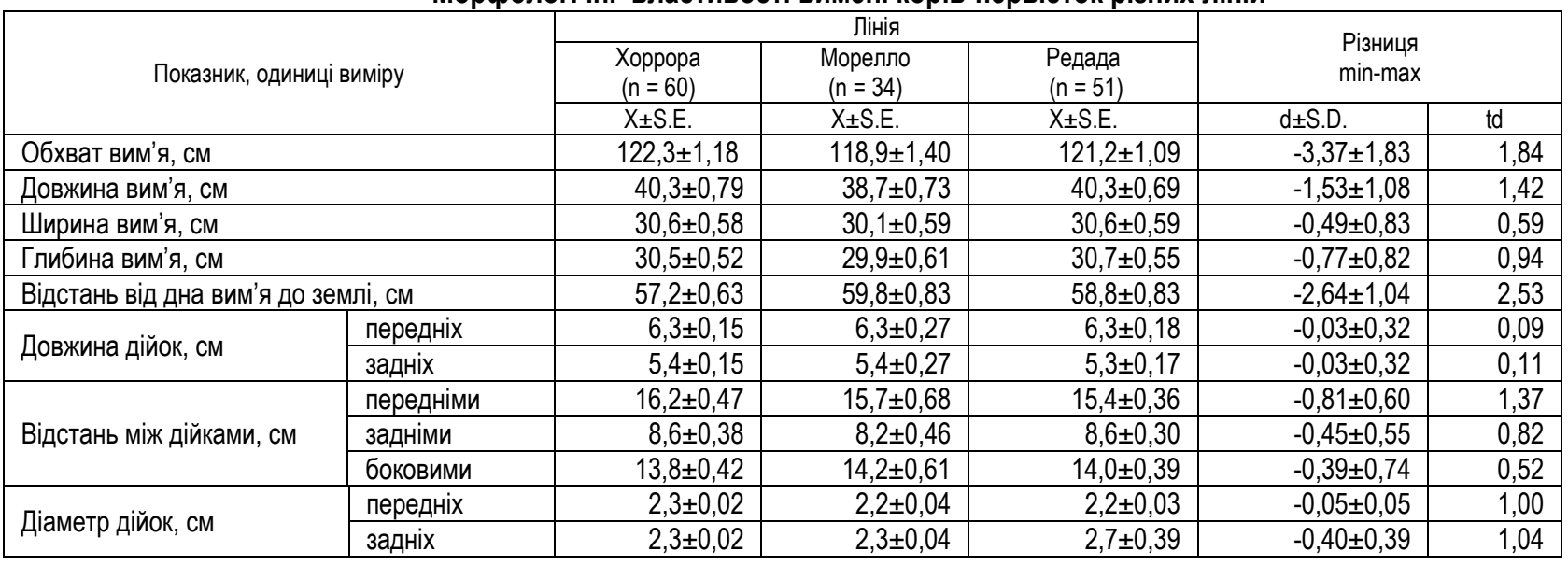

Загалом обстежені тварини стада характеризуються добре розвиненим пропорційним вимям в основному ванноподібної форми з великим запасом, міцною підтимуючою зв'язкою. Молочні вени товсті, довгі, звивисті, добре розгалужені. Дійки циліндричної та конічної форми розміщені по середині часток вим'я по квадрату. Консистенція вим'я залозиста дрібнозерниста та крупнозерниста. Конфігурація дна вим'я горизонтальна та розміщена на оптимальній довжині від землі. Тобто тварини даного стада повністю відповідають вимогам технології машинного доїння.

Значних відмінностей між тваринами різних ліній за морфологічними властивостями вим'я не вдалося встановити. Зокрема обхват вим'я коливався від 118,9 до 122,3 см, довжина 38,7 і 40,3 см, ширина 30,1 і 30,6 см, глибина 29,9 і 30,7 см, відстань від дна вим'я до землі 57,2 і 59,8, довжина передніх дійок 6,3 см в усіх групах, задніх - 5,3 і 5,4 см, відстань між передніми дійками 15,4 і 16,2 см, задніми - 8,2 і 8,6 см, боковими - 13,8 і 14,0.

Міжгрупова різниця у більшості варіантах порівнянь була статистично невірогідною. Вірогідною різниця виявилась лише між тваринами лінії Хоррора і Морелла за відстанню дна вим'я до землі на користь дочок бугаїв лінії Морелла (2,64 cм td 2.64). Критерій достовірності Стьюдента коливався у межах 0,02 до 2,53. Узагальнюючий критерій достовірності Стьюдента між групами становив: ХоррорМорелло - 0,89, Морелло-Редада - 0,54; Хоррор-Редада 0,70, тобто максимальна різниця спостерігалась між тваринами ліній Хоррора та Морелло, мінімальна - Морелла та Редада.

Основним завданням селекційно-племінної роботи у молочному скотарстві $є$ підвищення молочної продуктивності корів, яка визначається їх генотипом та умовами вирощу- 
вання, годівлі та використання. Селекційне поліпшення всіх структурних елементів породи потребує обґрунтування оптимальних шляхів досягнення максимального генетичного прогресу. Все це в комплексі, зумовлює проведення постійного моніторингу селекційних ознак, як у середині породи, так і у окремих стадах [11-13]. При характеристиці корів окремих стад за ознаками молочної продуктивності необхідно враховувати їхню генеалогічну структуру. Оскільки роз- ведення за лініями $є$ одним із основних і ефективних методів покращення продуктивних якостей корів молочного напрямку продуктивності.

Нашими дослідженнями було встановлено, що молочна продуктивність корів-первісток симентальської породи ПП «Галекс-Агро» значною мірою обумовлена їх лінійною належністю (табл. 3).

Молочна продуктивність корів-первісток різних ліній

\begin{tabular}{|c|c|c|c|c|c|}
\hline \multirow{3}{*}{ Показник, одиниці виміру } & \multicolumn{3}{|c|}{ Лінія } & \multirow{2}{*}{\multicolumn{2}{|c|}{$\begin{array}{l}\text { Різниця } \\
\text { min-max }\end{array}$}} \\
\hline & $\begin{array}{c}\text { Xoppopa } \\
(n=60)\end{array}$ & $\begin{array}{c}\text { Морелло } \\
(n=34)\end{array}$ & $\begin{array}{l}\text { Редада } \\
(n=51)\end{array}$ & & \\
\hline & $X \pm S . E$. & $X \pm$ S.E. & $X \pm S . E$. & $d \pm S . D$. & td \\
\hline Тривалість лактації, днів & $353,5 \pm 8,39$ & $346,18 \pm 9,47$ & $356,8 \pm 9,06$ & $-10,5 \pm 13,1$ & 0,81 \\
\hline Надій за лактацію, кг & $8028 \pm 256,8$ & $7797 \pm 337,2$ & $8466 \pm 330,2$ & $-669,2 \pm 472,0$ & 1,42 \\
\hline Надій за 305 днів лактації, кг & $6635 \pm 135,2$ & $6593 \pm 214,1$ & $7142 \pm 181,0$ & $-548,3 \pm 280,3$ & 1,99 \\
\hline Жирномолочність, \% & $4,31 \pm 0,04$ & $4,29 \pm 0,05$ & $4,26 \pm 0,04$ & $+0,05 \pm 0,06$ & 0,83 \\
\hline Молочний жир, кг & $285,1 \pm 5,92$ & $281,40 \pm 8,73$ & $303,1 \pm 7,39$ & $-21,7 \pm 11,4$ & 1,98 \\
\hline Білковомолочність, \% & $3,54 \pm 0,03$ & $3,48 \pm 0,03$ & $3,53 \pm 0,03$ & $-0,05 \pm 0,04$ & 1,09 \\
\hline Молочний білок, кг & $233,9 \pm 4,61$ & $229,1 \pm 7,19$ & $251,9 \pm 6,61$ & $-22,8 \pm 9,7$ & 2,34 \\
\hline Молочний жир і білок, кг & $519,0 \pm 10,30$ & $510,49 \pm 15,62$ & $555,0 \pm 13,73$ & $-44,5 \pm 20,7$ & 2,14 \\
\hline Відносна молочність, кг & $1179 \pm 30,4$ & $1157 \pm 36,9$ & $1237 \pm 35,7$ & $-79,7 \pm 51,3$ & 1,55 \\
\hline
\end{tabular}

Зокрема, надій за 305 днів лактації коливався від 6593 до 7142 кг, жирномолочність - 4,26-4,31, молочний жир - 281,40-303,1, білковомолочність 3,48-3,53, молочний білок - 229,1-251,9, молочний жир і білок - 510,5-555,0, відносна молочність - 1157,5-1237,3 кг. Тобто, кращими за кількісними показниками молока виявилися тварини лінії Редада, гіршими - Морелла. За якісними показниками спостерігається менш контрастніша різниця, максимальний вміст жиру у молоці спостерігався у корів лінії Хоррора, мінімальний Реддада.

Тварини лінії Редада достовірно переважали ровесниць ліній Хоррора та Морелло за більшістю кількісних показників молочної продуктивності, за якісними показниками (вмістом жиру та білка у молоці) вірогідної міжгрупової різниці не було встановлено. Різниця між лініями у $30 \%$ випадків виявилась достовірною. Максимальна різниця за показниками молочної продуктивності спостерігалась між лініями Морелло та Редада, яка у 50 \% випадків виявилась достовірною і середній узагальнюючий критерій достовірності Стьюдента становив 1,53. Мінімальна різниця - між лініями Хоррора та Морелло, яка у всіх варіантах порівнянь виявилась недостовірною і критерій достовірності становив
0,52, між лініями Хоррора та Редада - 1,34.

Відтворювальна здатність - важлива складова комплексної оцінки молочної та комбінованої худоби. Сучасні програми селекції молочної худоби поряд з молочною продуктивністю та екстер'єрним типом обов'язково враховують відтворювальну здатність корів. Щорічні отелення сприяють рентабельному виробництву молока, а регулярне одержання телят дає змогу проводити селекційно-племінну роботу на високому рівні та служить передумовою розширеного відтворення стада. Відтворення молочної худоби - селекційний процес, у якому поєднуються біологічні, селекційні, технологічні та організаційно-економічні фактори. Тварини, яких відбирають для племінного використання, повинні мати не тільки високі племінні, а й відповідні відтворювальні якості [14-17].

У зв'язку з вище зазначеним, поряд з молочною продуктивністю та екстер'єром, нами також було вивчено вплив лінійної належності на відтворення корів. Оскільки ефективність використання тієї чи іншої ліній визначається не лише молочною продуктивністю, а і здатністю до відтворення (табл. 3).

Відтворна здатність корів-первісток різних груп

\begin{tabular}{|c|c|c|c|c|c|}
\hline \multirow{3}{*}{ Показник, одиниці виміру } & \multicolumn{3}{|c|}{ Лінія } & \multirow{2}{*}{\multicolumn{2}{|c|}{$\begin{array}{l}\text { Різниця } \\
\text { min-max }\end{array}$}} \\
\hline & $\begin{array}{c}\text { Xoppopa } \\
(n=60)\end{array}$ & $\begin{array}{c}\text { Морелло } \\
(\mathrm{n}=34)\end{array}$ & $\begin{array}{l}\text { Редада } \\
(\mathrm{n}=51)\end{array}$ & & \\
\hline & $X \pm S . E$. & $X \pm S . E$. & $X \pm S . E$. & $d \pm S . D$. & td \\
\hline Вік 1-го отелу, днів & $850,1 \pm 10,36$ & $870,0 \pm 27,73$ & $846,9 \pm 10,2$ & $+23,1 \pm 29,5$ & 0,78 \\
\hline Сервіс період, днів & $123,1 \pm 6,82$ & $121,1 \pm 8,16$ & $127,5 \pm 7,40$ & $-6,3 \pm 11,02$ & 0,58 \\
\hline Сухостійний період, днів & $52,62 \pm 1,25$ & $55,9 \pm 1,64$ & $54,9 \pm 1,16$ & $-3,3 \pm 2,06$ & 1,63 \\
\hline Міжотельний період, днів & $404,4 \pm 7,67$ & $401,6 \pm 8,77$ & $412,2 \pm 8,60$ & $-10,5 \pm 12,2$ & 0,86 \\
\hline Тривалість тільності, днів & $281,3 \pm 1,45$ & $280,5 \pm 1,43$ & $284,6 \pm 1,94$ & $-4,1 \pm 2,41$ & 1,71 \\
\hline Коефіцієнт відтворної здатності & $0,92 \pm 0,02$ & $0,92 \pm 0,02$ & $0,90 \pm 0,02$ & $+0,02 \pm 0,03$ & 0,70 \\
\hline
\end{tabular}

Нами встановлено, що параметри відтворної здатності корів різних ліній ПП «Галекс-Агро» наближаються до оптимальних. Так, вік першого отелення корів-первісток різних ліній варіював в межах 846,9-870,1 днів, сервіс період - 121,1-127,5 днів, міжотельний період - 401,6-412,2 днів, період тільності - 280,5-284,6 сухостійний період - 52,6-55,9 днів. Коефіцієнт відтворної здатності у тварин різних ліній коливався від 0,90 до 0,92.

Проте різниця за відтворною здатністю між коровами різних ліній у всіх була не достовірною $(P>0,05)$. Однак, 
спостерігається деяка тенденція - тварини, які мають вищу молочну продуктивність відповідно характеризуються гіршими показниками відтворення. Яскравим підтвердженням даного аргументу є малюнок 1 .

Поєднання в одному генотипі тварин високої продуктивності з оптимальними репродуктивними якостями $€$ споконвічною проблемою для селекціонерів у більшості госпо- дарствах. Однак, у даному господарстві тварини як в цілому по господарству, так і у межах ліній характеризуються високою молочною продуктивністю і наближеними до оптимальних параметрами відтворної здатності. Це було досягнуто шляхом створення оптимальних умов утримання, годівлі та використання тварин, а також чіткого дотримання технології штучного осіменіння і виявлення тварин в охоті.

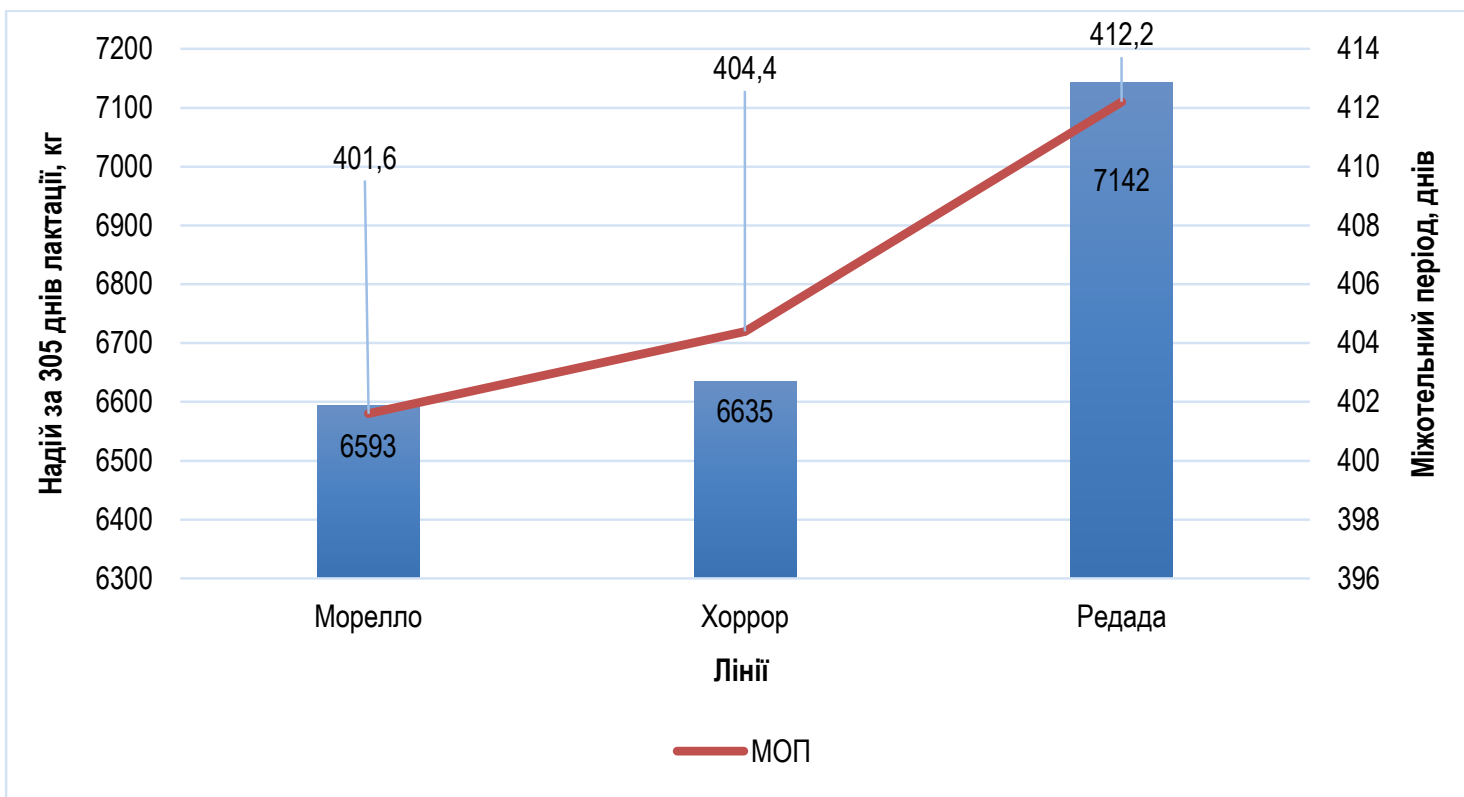

Puc. 1. Залежність продуктивності корів-первісток від їх лінійної належності

Важливими компонентами апробації та подальшого генетичного прогресу порід та їхніх ліній, родин, типів $є$ фенотипова та генетична специфічність та певний ступінь консолідованості [18].

Головною особливістю лінії є властива її представницям консолідованість за господарськи корисними ознаками внаслідок спорідненості та спрямованого добору й підбору, що робить лінію деякою мірою відмінною від інших [19].

За ступенем фенотипової консолідації (рис. 2) лінії за всіма блоками вивчених ознак в середньому розмістились у такій послідовності: лінія Хоррора $(+0,14)$, Моррела $(+0,10)$, Редада $(+0,04)$.

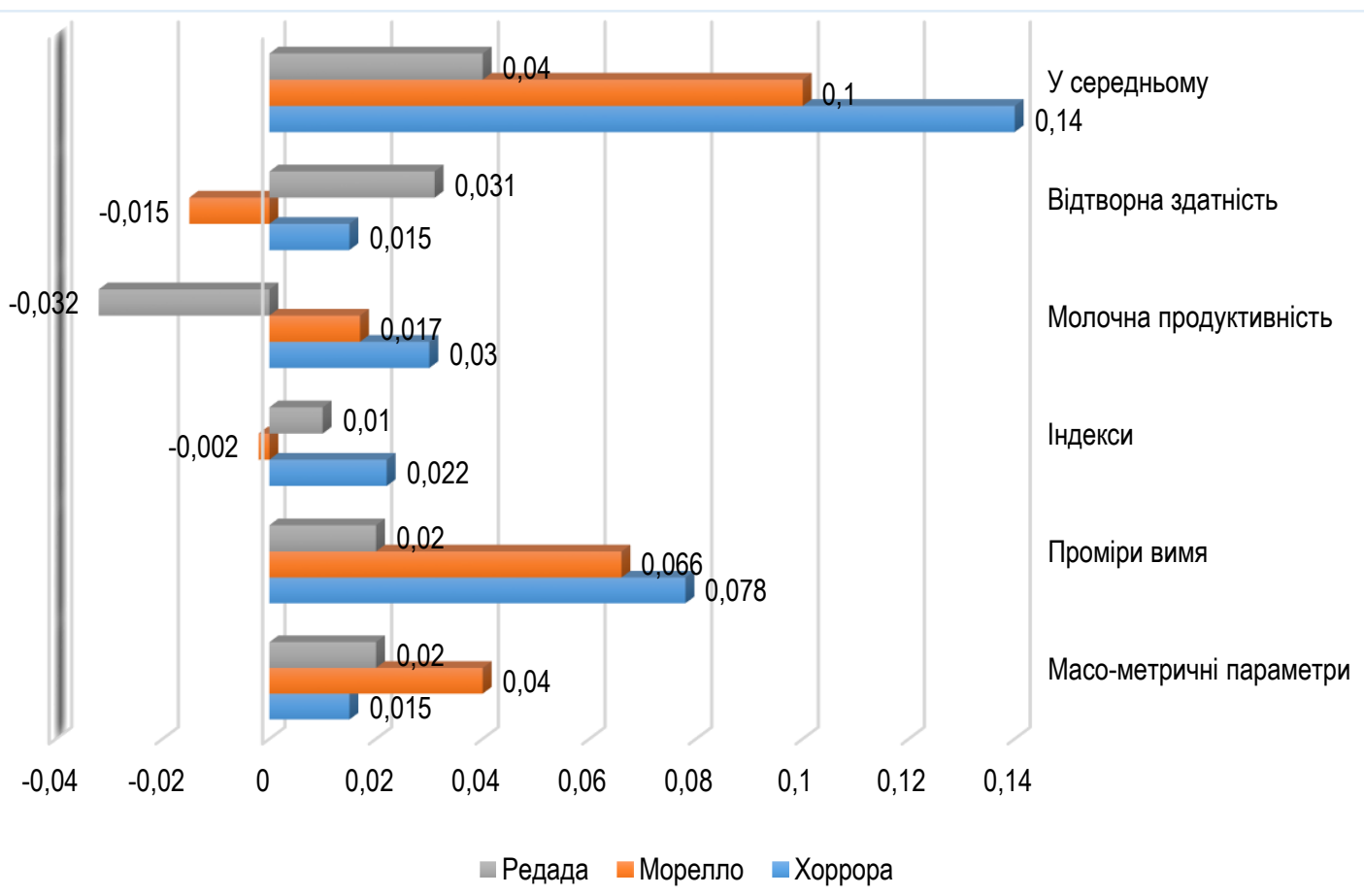

Puс. 2. Ступінь фенотипової консолідації тварин різних ліній за блоками вивчених ознак 
Тобто, значення коефріцієнтів фенотипової консолідації тварин різних ліній характеризуються додатнім значенням і незначною мінливістю. Варто відмітити, що серед усіх блоків досліджуваних ознак у межах ліній від'ємні коефріцієнти фенотипової консолідації виявилися лише у тварин лінії Редада (молочна продуктивність -0,032) та Морелло (індекси будови тіла -0,002). Тварини всіх ліній характеризуються майже однаковими додатними значеннями коефіцієнтів фенотипової консолідації за всіма блоками вивчених ознак, що свідчить про високий рівень селекційної роботи у даному стаді.

Висновки. 1. Кращими за живою масою та більшістю промірів будови тіла виявилися корови лінії Редада, нижчими показниками даних ознак характеризувалися тварини ліній Хоррора і Морелла, однак різниця між групами у всіх випадках виявилася не достовірною.

2. Тварини стада ПП «Галекс-Агро» повністю відповідають вимогам технології машинного доїння і характеризуються добре розвиненим пропорційним вим'ям в основному ванноподібної форми з великим запасом, міцною підтри- муючою зв'язкою. Молочні вени товсті, довгі, звивисті, добре розгалужені. Дійки циліндричної та конічної форми розміщені по середині часток вим'я по квадрату.

3. Кращими за кількісними показниками молока виявилися тварини лінії Редада, гіршими - Морелла. За якісними показниками спостерігається менш контрастніша різниця, максимальний вміст жиру у молоці спостерігався у корів лінії Хоррора, мінімальний - Реддада. Різниця між лініями у 30 \% випадків виявилась вірогідною. Різниця за відтворною здатністю між коровами різних ліній у всіх випадках була не достовірною ( $P>0,05)$. Однак, спостерігається деяка тенденція - тварини, які мають вищу молочну продуктивність відповідно характеризуються гіршими показниками відтворення.

4. За ступенем фенотипової консолідації лінії за всіма блоками вивчених ознак в середньому розмістились у такій послідовності: лінія Хоррора $(+0,14)$, Моррела $(+0,10)$, Редада $(+0,04)$. Тобто, значення коефіцієнтів фенотипової консолідації тварин різних ліній характеризуються додатнім значенням і незначною мінливістю.

\section{Список використаної літератури:}

1. Буркат В. П., Полупан Ю. П. Розведення тварин за лініями: генезис понять і методів та сучасний селекційний контекст. К. : Аграр. наука, 2004. 68 с.

2. Єфріменко М., Коваленко Г., Бірюкова О. Перспективи розвитку генеалогічної структури української чорно-рябої молочної породи. Тваринництво України. 2002. № 12. С. 35-36.

3. Проблеми питання розведення тварин за лініями / Й. Сірацький та ін. Тваринництво України. 2005. № 9. С. $16-17$.

4. Вінничук Д. Т. Основні принципи розведення за лініями в скотарстві. Молочно-м'ясне скотарство. К.. 1979. Вип. 49. C. 96 .

5. Симентальська порода / В. П. Буркат та ін. Племінні ресурси України. 1998. К.: Аграрна наука. С. 36-40.

6. Почукалін А. Є., Різун О. В., Прийма С. В. Моніторинг симентальської породи в Україні. Розведення і генетика тварин. 2017. Вип. 53. С. 179-184.

7. Полупан Ю. П. Методи визначення ступеня генотипової консолідації селекційних груп тварин. Методики наукових досліджень із селекції, генетики та біотехнології у тваринництві. К. : Аграр. наука, 2005. С. 52-61.

8. Хмельничий Л. М. Оцінка екстер'єру тварин в системі селекції молочної худоби : монографрія. Суми : Мрія, 2007 $260 \mathrm{c}$.

9. Бащенко М.І., Хмельничий Л.М. Морфологічні властивості вимені молочної худоби. Вісник Черкаського інституту агропромислового виробництва. Вип. 4. 2004. С. 21-32.

10. Пелехатий М.С., Піддубна Л.М., Кучер Д.М., Кочук-Ященко О.А. Масо-метричні параметри тулуба корів-первісток голштинської та українських чорно-рябої і червоно-рябої молочних порід в умовах молочного комплексу. Вісник Сумського нац. аграр. ун-ту. Наук. журнал. Серія «Тваринництво». Суми. 2016. Вип. 7 (30). С. 82-88.

11. Вплив генетичних і паратипових чинників на господарськи корисні ознаки корів / М. В. Гладій та ін. Розведення і генетика тварин. 2014. № 48. С. 48-61.

12. Коваленко Г. С., Бірюкова О.Д. Сучасний стан розведення за лініями в українській чорно-рябій молочній породі. Розведення і генетика тварин. 2005. Вип. 38. С.152-158.

13. Пелехатий М. С., Кучер Д. М. Ефективність використання кросів ліній в заводському стаді української чорно-рябої молочної породи. Вісник Житомирського національного агроекологічного університету. 2012. № 2 (1). С. $141-150$.

14. Коваль Т. П. Вплив віку першого отелення на відтворну здатність корів. Вісник аграрної науки. 2008. № 11. С. 2932.

15. Новак І. В., Федорович В. В., Федорович Є. І. Вплив віку першого плідного осіменіння і першого отелення на формування молочної продуктивності корів української чорно-рябої молочної породи. Біологія тварин. Львів, 2012. Т. 14. № 1-2. C. $486-490$

16. Титаренко І. В., Буштрук М. В., Старостенко І. С. Відтворна здатність корів залежно від генеалогічної належності. 3б. наук. праць Вінницького НАУ. 2011. № 8 (48). С.74-77.

17. Шарапа Г. С. Відтворна здатність корів нових порід і генотипів Теоретичні й практичні аспекти породоутворювального процесу у молочному та м'ясному скотарстві. К.: Ас. Україна, 1995. С. 323-324.

18. Полупан Ю. П., Рєзникова Н. Л., Гавриленко М. С. Визначення фенотипової консолідованості селекційних груп тварин на популяційному рівні. Методологія наукових досліджень з питань селекції, генетики та біотехнології у тваринництві: матеріали наук. -теорет. конф. присвяченої пам'яті акад. УААНВ. П. Бурката, (Чубинське, 25 лютого 2010 р.). К.: Аграрна наука, 2010. С. 98-100.

19. Хмельничий С. Л. Оцінка екстер'єру тварин сумського внутрішньопородного типу української чорно-рябої молоч- 
ної породи: дис. канд. с.-г. наук : 06.02.01 Нац. акад. аграр. наук України, Ін-т розведення і генетики тварин ім. М. В. Зубця. С. Чубинське Київ. обл., 2017. 222 с.

\section{References:}

1.Burkat, V. P. and Polupan Yu. P., 2007. Rozvedennia tvaryn za liniiamy: henezys poniat i metodiv ta suchasnyi selektsiinyi kontekst [Breeding animals along lines: the genesis of concepts and methods and the modern breeding context]. K.: Ahrarna nauka.

2. lefimenko, M., Kovalenko, H., and Biriukova, O., 2002. Perspektyvy rozvytku henealohichnoi struktury ukrainskoi chornoriaboi molochnoi porody [Prospects for the development of the genealogical structure of the Ukrainian Black-and-White dairy breed]. Tvarynnytstvo Ukrainy, no 12, pp. 35-36.

3. Siratskyi, Y., 2005. Problemy pytannia rozvedennia tvaryn za liniiamy [Problems of animal breeding along the lines]. Tvarynnytstvo Ukrainy, no 9, pp. 16-17.

4. Vinnychuk, D.T., 1979. Osnovni pryntsypy rozvedennia za liniiamy v skotarstvi [Basic principles of breeding lines in livestock]. Molochno-miasne skotarstvo, no. 49, pp. 96.

5. Burkat, V. P. and others.Symentalska poroda [Simmental breed]. Pleminni resursy Ukrainy. K.: Ahrarna nauka.

6. Pochukalin, A. Ye., Rizun, O. V. and Pryima, S. V., 2017. Monitorynh symentalskoi porody v Ukraini [Monitoring of Simmental breed in Ukraine]. Rozvedennia i henetyka tvaryn, no. 53, pp. 179-184.

7. Polupan, Yu. P., 2005. Metody vyznachennia stupenia henotypovoi konsolidatsii selektsiinykh hrup tvaryn [Methods for determining the degree of genotypic consolidation of breeding groups of animals]. Metodyky naukovykh doslidzhen iz selektsii, henetyky ta biotekhnolohii u tvarynnytstvi, pp. 52-61.

8. Khmelnychyi, L. M., 2007. Otsinka eksterieru tvaryn v systemi selektsii molochnoi khudoby : monohrafiia [Evaluation of the exterior of animals in the system of selection of dairy cattle: a monograph]. Sumy : Mriia.

9. Bashchenko, M.I. and Khmelnychyi, L.M., 2004. Morfolohichni vlastyvosti vymeni molochnoi khudoby [Morphological properties of the udder of dairy cattle]. Visnyk Cherkaskoho instytutu ahropromyslovoho vyrobnytstva, no. 4, pp. 21-32.

10. Pelekhatyi, M.S., Piddubna, L.M., Kucher, D.M. and Kochuk-Yashchenko, O.A., 2016. Maso-metrychni parametry tuluba koriv-pervistok holshtynskoi ta ukrainskykh chorno-riaboi i chervono-riaboi molochnykh porid v umovakh molochnoho kompleksu [Mass-metric parameters of the body of first-born cows of Holstein and Ukrainian black-white and red-white dairy breeds in the conditions of the dairy complex]. Visnyk Sumskoho nats. ahrar. un-tu. Nauk. zhurnal. Seriia «Tvarynnytstvo», no. 7 (30), pp. 82-88.

11. Hladii, M. V. and others, 2014. Vplyv henetychnykh i paratypovykh chynnykiv na hospodarsky korysni oznaky koriv [Influence of genetic and paratypic factors on economically useful traits of cows]. Rozvedennia i henetyka tvaryn, no 48, pp. 48-61.

12. Kovalenko, H. S. and Biriukova, O. D., 2005. Suchasnyi stan rozvedennia za liniiamy v ukrainskii chorno-riabii molochnii porodi [The current state of breeding along the lines in the Ukrainian black-and-white dairy breed]. Rozvedennia i henetyka tvaryn, no. 38, pp. 152-158.

13. Pelekhatyi, M. S. and Kucher, D. M., 2012. Efektyvnist vykorystannia krosiv linii v zavodskomu stadi ukrainskoi chornoriaboi molochnoi porody [The efficiency of using cross lines in the factory herd of Ukrainian black-and-white dairy breed]. Visnyk Zhytomyrskoho natsionalnoho ahroekolohichnoho universytetu, no 2 (1), pp. 141-150.

14. Koval, T. P., 2008. Vplyv viku pershoho otelennia na vidtvornu zdatnist koriv [Influence of the age of the first calving on the reproductive capacity of cows]. Visnyk ahrarnoi nauky, no 11, pp. 29-32.

15. Novak, I. V., Fedorovych, V. V. and Fedorovych, Ye. I., 2012. Vplyv viku pershoho plidnoho osimeninnia i pershoho otelennia na formuvannia molochnoi produktyvnosti koriv ukrainskoi chorno-riaboi molochnoi porody [Influence of the age of the first fertile insemination and the first calving on the formation of milk productivity of cows of the Ukrainian black-sand-white dairy breed]. Biolohiia tvaryn, T. 14, no. 1-2., pp. 486-490.

16. Tytarenko, I. V., Bushtruk, M. V. and Starostenko I. S., 2011. Vidtvorna zdatnist koriv zalezhno vid henealohichnoi nalezhnosti [Reproductive capacity of cows depending on genealogical affiliation]. Zb. nauk. prats Vinnytskoho NAU, no. 8 (48), pp. 74-77.

17. Sharapa, H. S., 1995. Vidtvorna zdatnist koriv novykh porid i henotypiv [Reproductive ability of cows of new breeds and genotypes]. Teoretychni y praktychni aspekty porodoutvoriuvalnoho protsesu u molochnomu ta miasnomu skotarstvi, pp. 323-324.

18. Polupan, Yu. P., Rieznykova, N. L. and Havrylenko, M. S., 2010. Vyznachennia fenotypovoi konsolidovanosti selektsiinykh hrup tvaryn na populiatsiinomu rivni [Determination of phenotypic consolidation of selection groups of animals at the population level]. Metodolohiia naukovykh doslidzhen z pytan selektsii, henetyky ta biotekhnolohii u tvarynnytstvi : materialy nauk.teoret. konf., prysviachenoi pamiati akad. UAANV. P. Burkata, (Chubynske, 25 liutoho 2010 r.). K. : Ahrarna nauka,pp. 98-100.

19. Khmelnychyi, S. L., 2017. Otsinka eksterieru tvaryn sumskoho vnutrishnoporodnoho typu ukrainskoi chorno-riaboi molochnoi porody: dys. kand. s.-h. nauk : 06.02.01 Nats. akad. ahrar. nauk Ukrainy, In-t rozvedennia i henetyky tvaryn im. M. V. Zubtsia [Estimation of an exterior of animals of the Sumy intrabreed type of the Ukrainian black-spotted dairy breed: dis. Cand. s.-g. Science: 06.02.01 Nat. acad. agrarian. Sciences of Ukraine, Institute of Animal Breeding and Genetics. MV Zubets]. c. Chubynske Kyiv. obl.

20. Хмельничий С. Л. Оцінка екстер'єру тварин сумського внутрішньопородного типу української чорно-рябої молочної породи: дис. канд. с.-г. наук : 06.02.01 Нац. акад. аграр. наук України, Ін-т розведення і генетики тварин ім. М. В. Зубця. С. Чубинське Київ. обл., 2017. 222 с. 
Kochuk-Yashchenko Oleksandr Anatoliiovych, Ph.D. of agricultural sciences

Kucher Dmytro Mykolaiovych, Ph.D. of agricultural sciences

Lobodzinskyi Valentyn, Undergraduate

Holiak Vadym, Undergraduate

Polissia National University (Zhytomyr, Ukraine)

Economic useful features of Simental breed cows of different linears in conditions of organic production

The article presents the results of comparative evaluation of first-born cows of the Simmental breed of Czech selection of different linear affiliation in organic milk production in the conditions of PE "Galex-Agro". The first-born cows of the studied lines do not differ significantly in live weight and basic body measurements. In general, the first-born cows of the Simmental breed of the herd PE "Galex-Agro" are characterized by a proportionate body structure. They are high-legged (height at the withers and in the buttocks, respectively 134.8-135.3 and 141.6-142.1 sm) with deep and well developed chest (chest depth and chest girth - 73.5-73.8 and 203.4-204.6) both in width (width of the chest behind the shoulders 50.2-50.9) and in length (length breast 80.0-80.4) with a live weight of 610.6-618.3 kg. Cows have a wide back, which provides ease of calving (width in the hips and buttocks, respectively, 51.251.7 and 32.4-32.6 cm). The size of the animals by the main measurements of body structure in combination with a large live weight within the lines indicates the formation of the milk type of the exterior of the first-born Simmental cows of the Czech selection PE "Galex-Agro". The main indices of the body structure of cows of the whole herd and within the lines correspond to the dairy type of animals and testify to the harmony and good proportional development of all parts of body. Significant differences between animals of different lines on the morphological properties of the udder could not be established. In particular, the girth of the udder ranged from 118.9 to $122.3 \mathrm{sm}$, length 38.7 and 40.3, width 30.1 and 30.6, depth 29.9 and $30.7 \mathrm{~cm}$, the distance from the bottom of the udder to the ground 57.2 and 59.8, the length of the front teats 6.3 in all groups, the rear -5.3 and 5.4, the distance between the front teats 15.4 and 16.2, the rear - 8.2 and 8.6, lateral - 13.8 and 14.0. The animals of the Redada line significantly outperformed the Horror and Morello peers in most quantitative indicators of milk productivity, and no significant intergroup difference was found in terms of qualitative indicators (protein milk and fat content). The difference between the lines in $30 \%$ of cases was significant. The maximum difference in milk productivity was observed between the Morello and Redada lines, which in $50 \%$ of cases was reliable and the average generalizing criterion of Student's reliability was 1.53. The values of the coefficients of phenotypic consolidation of animals of different lines are characterized by a positive value and insignificant variability. It should be noted that among all blocks of the studied traits within the lines, negative coefficients of phenotypic consolidation were found only in animals of the Redada line (milk productivity -0.032) and Morello (body structure indices -0.002).

Key words: Simmental breed, organic production, exterior, body measurements, indices, udder, consolidation.

Дата надходження до редакції: 16.04.2021 р. 